\title{
Legislation governing the implementation of small-scale hydropower projects for rural electrification in South Africa
}

\author{
Beate Scharfetter*, Marco van Dijk \\ University of Pretoria, Faculty of Engineering, Built Environment \& IT, Private bag X20, Hatfield 0028, \\ Pretoria, South Africa
}

\begin{abstract}
The Department of Energy's 'new household electrification strategy' allows for any appropriate and affordable technology option to be applied towards achieving South Africa's non-grid electrification target of 300000 households over the period 2014 to 2025. This paper describes the main legislative and regulatory framework governing the implementation of small-scale hydropower (SHP) projects in South Africa with the aim of attaining the objectives of the non-grid electrification component of the 'new household electrification strategy', and indicates that it is possible to implement such projects within South Africa's complex institutional architecture. The inclusion of run-of-river type small-scale hydropower projects for rural electrification in the 2016 updated General Authorisation eased the process of attaining regulatory compliance in terms the National Water Act. This implies that these types of SHP projects would only need to follow a registration process to obtain the required water use authorisation, and not a full water use licence application process.
\end{abstract}

Keywords: non-grid electrification, 'new household electrification strategy', regulatory requirements, general authorisation

\section{Highlights}

- Appropriate and affordable technology option applied towards achieving the non-grid electrification target in South Africa.

- Small-scale hydropower applied as an appropriate energy solution.

- Legislation and regulations governing the implementation of small-scale hydropower for non-grid electrification in South Africa.

Journal of Energy in Southern Africa 28(2): 14-28

DOI: http://dx.doi.org/10.17159/2413-3051/2017/v28i2a2005

Published by the Energy Research Centre, University of Cape Town ISSN: 2413-3051 http://journals.assaf.org.za/jesa

Sponsored by the Department of Science and Technology

\footnotetext{
* Corresponding author: Tel: +27 82468 8461;

email: beate.scharfetter@gmail.com
} 


\section{Introduction}

The portion of the populace impacted most severely by events such as droughts, water restrictions and electricity interruptions is the rural poor, whose ability to adapt and respond to such events is low. Adjusting the approach of Downing (2011), one can surmise that adaptation to external events fundamentally entails 'good development' as well as building the adaptive capacity of all stakeholders. Downing's approach recognises a continuum of strategies, from 'good development' through to actions targeted at reducing future impacts of external events. 'Good development' in a South African context would entail providing all members of society with at least a basic level of service for water, sanitation and electricity as well as access to basic social services such as health and education. The Reconstruction and Development Programme White Paper of 1994 laid the foundation for South Africa's developmental trajectory, focusing inter alia on providing basic water, sanitation, electricity, healthcare and education infrastructure and infrastructure services to all the people of South Africa (South Africa, 1994). The government was able to provide at least a basic electricity service to $86 \%$ of the population (DoE, 2014) between 1994 and 2013 , with the backlog mainly in rural areas where topography, location and available technology pose challenges to extending the distribution grid, resulting in increased electricity connection costs. Alternative technological means are required to provide electricity to sparsely populated areas where low potential demand makes it economically unfeasible to provide grid-connected electricity.

\section{New household electrification strategy}

In June 2013, the Cabinet approved the 'new household electrification strategy' of the Department of Energy (DoE). This strategy extends the target date for achieving universal access to a basic electricity service from 2014 to 2025 (DoE, 2013). The target has also been revised down from $100 \%$ to $97 \%$, with $90 \%$ of households to be connected to the grid and the remainder through high-quality and cost-effective non-grid technologies (DoE, 2013; Jamal, 2015). Prior to the new strategy, the non-grid portion of the electrification programme was to be implemented only by private concessionaires appointed by the DoE to provide solar home systems (SHSs) specifically, and within specific geographical areas. The 2013 strategy makes provision for implementing not only SHSs but any possible cost-effective technology. Furthermore, it is extending the roll-out of the non-grid programme countrywide, to those rural areas with low consumption and also to high-density urban areas where it is not possible to provide grid connections. An appropriate energy solution could be the application of small-scale hydropower (SHP) technology, either on its own or in hybrid formation, in conjunction with a mini-grid distribution system. In South Africa, typical hybrid formations would include SHP technology applied in conjunction with diesel generators and solar photovoltaic (PV) systems. A 2015 technical and economic evaluation of two mini-grid projects implemented previously in South Africa concluded, inter alia, that locations in close proximity to inland waterways suitable for hydropower provide the most competitive and optimal conditions for mini-grids to meet the energy needs of rural settlements' (Azimoh et al., 2015). The DoE estimates that the total number of nongrid households needing to be connected between 2014 and 2025 is approximately 300000 (DoE, 2013), with the highest potential for non-grid electrification initiatives lying in the Eastern Cape and KwaZulu-Natal provinces, as shown in Figure 1.

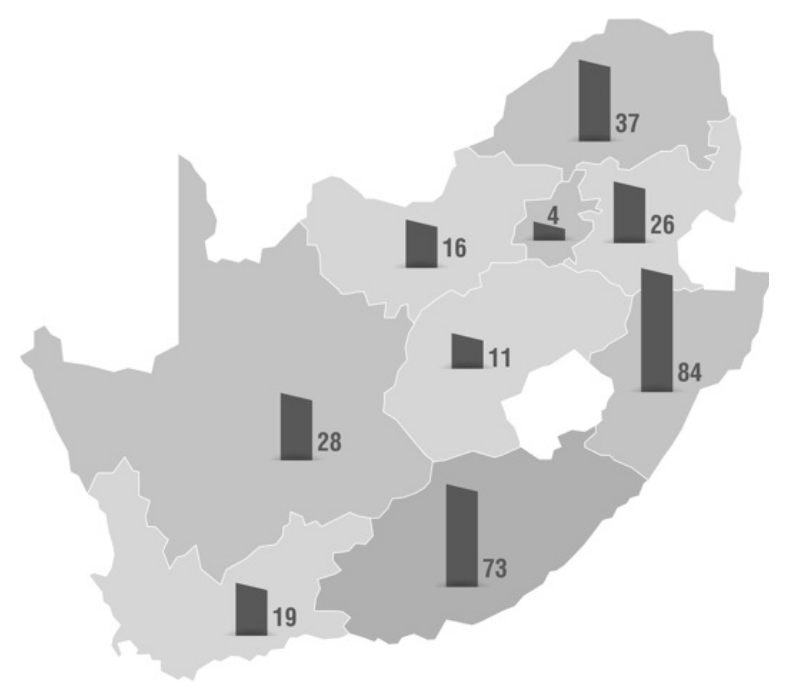

Figure 1: Anticipated number of households in 1000 s per province that potentially could benefit from non-grid electrification projects (DoE, 2013).

Taking into consideration that between 2002 and 2013 approximately 68000 non-grid household connections were made, mainly through stand-alone SHSs (DoE, 2013), the non-grid electrification programme will need to scale-up considerably, from an average of 6200 households per year over that period, to approximately 25000 per year for the period up to 2025 (see supplementary information). The operational mechanism through which both the non-grid and grid programmes are being rolled-out is the DoE's Integrated National Electrification Programme (INEP). The INEP was established during the 2001/02 financial year to address the backlog of households without electricity. At that time, it was planned that new household developments would be electrified through the restructured electricity distribution industry. Since the restructuring of the distribution industry did not occur, the INEP not only has to address the electri- 
fication backlogs but also the electrification of new household developments and informal households (DoE, 2013). The DoE uses Eskom and municipalities as implementing agents for the grid-connecting portion of the programme, and transfers funds to them to implement the objectives of the INEP. The funds need to address the development of various elements of electricity distribution, including building and upgrading sub-stations and distribution networks, and electrification of households (DoE, 2013).

Numerous regulatory and legislative requirements govern the implementation of small-scale hydropower schemes in South Africa. Pertinent legislation includes the Constitution, the Electricity Regulation Act (ERA), the National Water Act (NWA) and the National Environmental Management Act (NEMA). Figure 2 shows the context of this legislation in terms of a typical run-of-river hydropower scheme.

This paper describes the main legislative and regulatory framework governing the implementation of small-scale hydropower projects in South Africa with the aim of attaining the objectives of the non-grid electrification component of the new household electrification strategy, and to indicate that it is possible to implement SHP projects within South Africa's complex institutional architecture. The regulatory and legislative conditions governing an islanded mini-grid system eventually connecting to the interconnected electricity distribution grid are not addressed in this paper. The research for this paper was undertaken qualitatively through desktop studies and engagement with stakeholders including representatives of the Department of Energy, the National Energy Regulator of South Africa (NERSA), Eskom, the South African Local Government Association (SALGA), advisors to the Department of Energy, the Department of Water and Sanitation, City Power Johannesburg, the City of Tshwane Metropolitan Municipality, and the eThekwini Metropolitan Municipality. Private-sector stakeholders included electrical engineers and consultants, and environmental practitioners specialising in implementing the requirements of the NEMA and the NWA

\section{Small-scale hydropower}

Hydropower is generated when energy from falling or flowing water is converted into rotating shaft power by hydro-turbines, which can be used to drive an electricity generator or other machinery (Paish, 2002). Stated differently, 'the energy of flowing water is harnessed by turbines, which are placed in the path of the water flow. The force exerted by the water moving over turbine blades rotates the turbine runner; the turbine runner rotates the generator, which produces electricity' (Fichtner Management Consulting AG, 2015). The power available is proportional to the product of pressure head and volume flow rate. Topography and geography, as well as the hydrological flow regimes of a specific site, will dictate a unique hydropower plant design. This investigation was based on hydropower plants of size less than $1 \mathrm{MW}$, at any head, and predominantly run-of-river type schemes. Hydropower schemes of $10 \mathrm{MW}$ or less are generally classified as small-scale in South Africa, which collectively includes pico- (less than $20 \mathrm{~kW}$ ), micro- (less than $100 \mathrm{~kW}$ ) and mini- (less than $1 \mathrm{MW}$ ) sized schemes. Run-of-river schemes generate electricity by immediate use of the inflow, by diverting a portion or all of the river flow through a turbine. Typically, in run-of-river schemes, a low weir structure is built across a river to maintain a reasonably constant head of water. An intake structure is situated behind the weir, from where a canal would generally feed a forebay tank connected to a penstock (Loots et al., 2015). Most of these types of schemes have no, or very little, storage capacity and are subject to weather and seasonal variations. Importantly, run-of-river schemes do not consume water, due to the fact that the water diverted at the intake is released back into river after passing through the turbines. Figure 2 shows a typical runof-river hydropower scheme, indicating the main legislation governing the implementation of such a scheme.

An inherent risk of SHP technology is that it is dependent on perennial river flows, a risk which, in a semi-arid country such as South Africa, is increased during drought conditions. This risk is mitigated by analysing historical flow records of proposed sites as part of the site-selection process for SHP projects. Taking cognisance of this manageable risk, the application of small-scale hydropower is recognised as an appropriate technology for rural electrification for the following reasons (ARE, 2014; BHA, 2012; Paish, 2002; Taele et al., 2012):

- SHP seems to be the cheapest technology for rural electrification over the lifetime of a system. The initial capital costs of SHP projects are high, but operating costs are low. This is diametrically opposite to, for example, the application of a diesel generator, for which the initial capital cost is low but the operating costs are high. Kusakana (2014) identified suitable technology options, however, that would reduce the initial capital costs of a SHP, further improving the viability of SHP technology (Kusakana, 2014).

- SHP technology is mature, robust and reliable, with a proven track-record of longevity (50 years or more), and efficiency (70-90\%).

- It is a local energy source that makes use of small rivers. Stream flows are generally consistent, especially in comparison to the variability 


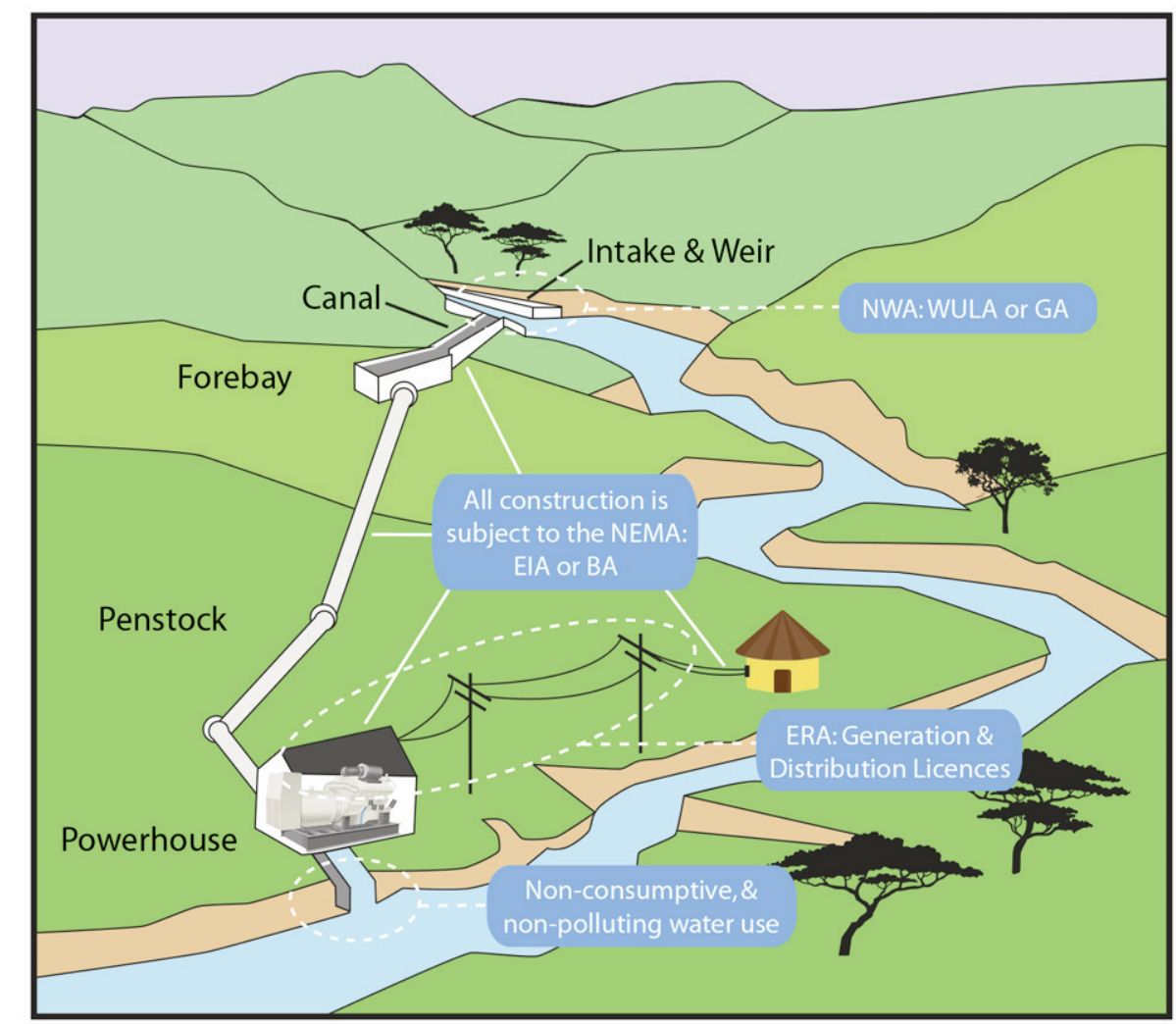

Figure 2: Typical run-of-river SHP indicating the main legislation governing its implementation in South Africa.

of solar and wind technologies, and therefore output can be calculated with a higher degree of reliability.

- Operation and maintenance of a SHP system is relatively simple and can be undertaken by appropriately trained local community members.

- It is an environmentally friendly and sustainable solution, which does not consume water.

- SHP technology can be retrofitted to existing infrastructure, establishing a multi-purpose scheme. For example, SHP plants can be retrofitted to existing dams or weirs or integrated into a water reticulation network or irrigation canal.

- Opportunities for implementing SHP exist in South Africa, in particular in the Eastern Cape and KwaZulu-Natal provinces (Jonker Klunne, 2012), mainly due to the prevalence of perennial rivers and mountainous or hilly topography. These areas align with the provinces identified by the DoE as having the greatest potential for non-grid electrification in South Africa.

\section{Energy policies and programmes from 1994 relevant to rural electrification}

The first phase of the predecessor to the INEP, the National Electrification Programme (NEP), was implemented between 1994 and 1999. The main objective of this programme was to address the immense electrification backlog in South Africa's rural and urban poor populations. This phase aimed to provide basic electricity to 2.5 million households, and it was to be funded by both the government and Eskom. Eskom undertook the task to provide nearly 300000 new connections per year over five years, or $66 \%$ of the total programme target, because the majority of the backlog was in rural areas (Bekker et al., 2008). Even though the NEP achieved a high number of rural connections during its initial period, which ran from 1994 to 2002 , the rural electrification component of the programme became a key focus only after 2002 (Bekker et al., 2008). This shift brought about an increase in connection costs, a decline in connection rates and the need to provide additional transmission infrastructure. Fundamental changes took place in government during 2000-2001, which included the decentralisation of service delivery functions from national to local government and the allocation of responsibility for basic service provision for low-income households to the then Department of Provincial and Local Government. This caused uncertainty within government as to where the INEP should be positioned. The decision to establish the INEP within the then Department of Minerals and Energy (DME) was only finalised in 2005. The introduction of the integrated development planning (IDP) process at local government level, as part of the decentralisation drive, also resulted in a change in the approach to electrification; whereas previously the focus was simply on 
ensuring connections, the IDP process required an integrated development approach (Bekker et al., 2008). Challenges with regards to the funding of the INEP also arose during this period. Though at first the NEP was funded jointly between government and Eskom, following the conversion of Eskom into a corporation in 2001 it was decided that Eskom would not provide capital funding for the INEP, which would receive funding directly and only from the fiscus (Bekker et al., 2008). As mentioned previously, the INEP is the main programme through which government is implementing its aim of achieving universal electrification, and therefore has a direct bearing on any rural electrification initiative.

The White Paper on Energy, promulgated in 1998, states that: 'Government recognises that household access to adequate energy services for cooking, heating, lighting and communication is a basic need. Whilst these needs can be met by various fuel-appliance combinations, government recognises that without access to electricity, a clean, convenient and desirable fuel, human development potential is ultimately constrained' (DME, 1998). From a demand perspective, this White Paper emphasised household connections for the lowincome, rural population. In this regard, it proposed that PV systems be provided to those rural communities too remote to be connected to the grid (Bekker et al., 2008), contributing to government's commitment to universal household access to electricity (Winkler et al., 2006). Further, the White Paper promoted energy-efficiency initiatives, particularly to industry, commerce and mining. From a supply perspective, it proposed restructuring the electricity distribution industry into independent regional distributors, and unbundling Eskom into separate generation and transmission companies (Nhamo \& Mukonza, 2016). Neither of these two proposals succeeded in practice; the proposed Independent System and Market Operator Establishment Bill, published for public comment in 2011, was not approved by parliament during 2015 (Le Cordeur, 2015), and the restructuring of the energy industry was abandoned by government in 2010 (Eberhard, 2013). Importantly, the 1998 White Paper shifted the responsibility for energy planning from Eskom to the DoE (DoE, 2015).

The White Paper on renewable energy, the integrated energy plan and the free basic electricity (FBE) policy came into effect in 2003, providing some institutional guidance towards the implementation of the off-grid SHS programme launched by government in 1999 in response to the proposals of the White Paper on Energy, which emphasised renewable energy options. The FBE policy was developed as a result of government's policy directive in 2000 relating to the provision of free basic water, sanitation and energy to poor households. The policy aims to alleviate poverty, with anticipat- ed associated positive spin offs for community health and the empowerment of women. The FBE policy allocates $50 \mathrm{kWh}$ per month of free electricity to grid-connected consumers, and further makes provision for FBE to non-grid energy consumers through (partially) subsidising both the once-off capital cost of the INEP SHS programme and the monthly service fee (see supplementary information). Alternative energy sources such as paraffin and gas are considered as options to complement rural electrification initiatives because a basic nongrid electrification level of services does not provide for heating and cooking needs (Azimoh et al., 2015).

The 2003 White Paper on Renewable Energy also proposed that government include private energy producers and renewable energy technologies in the electricity generation mix. Figure 3 shows a chronological development relationship of these policies and programmes.

\section{Legislation governing the implementation of small-scale hydropower projects for rural electrification}

The Constitution, Act No. 108 of 1996, laid down that generation of electricity is a national government function and, as per Schedule $4 \mathrm{~B}$, the reticulation (distribution) of electricity to consumers in their area of jurisdiction is a municipal function (South Africa, 1996). As electricity generation is not a local government function, municipalities have no 'original competence' to generate electricity, except where electricity generation is incidental to a local government function. Further, due to the fact that electricity generation is not listed in either Schedule $4 \mathrm{~B}$ or $5 \mathrm{~B}$ of the Constitution, electricity generation is deemed to be an exclusive national competence. A municipality can, though, derive competence for the electricity generation function through either a parliamentary executive delegation or a legislative assignment as per the Constitution (De Visser, 2012). Even though rural electrification projects using small-scale hydropower technology will entail, in effect, local municipalities generating and distributing electricity, these projects will be standalone systems, operating independently of the national transmission grid, and could therefore be considered to be similar in operation to the SHS programme. In addition, the provision of basic energy services to rural communities in South Africa fulfils local government's constitutional mandate to provide services to communities in a sustainable manner and promote social and economic development and a safe and healthy environment (South Africa, 1996, City of Cape Town, 2015). In the context, therefore, of the new household electrification strategy', non-grid, small-scale hydropower projects implemented by local municipalities are interpreted as falling within the ambit of the powers 
and functions allocated to local government by the Constitution (see supplementary information). The functional responsibilities listed in schedules $4 \mathrm{~B}$ and $5 \mathrm{~B}$ of the Constitution are shared between district and local municipalities. The allocation of responsibilities between district and local municipalities is governed by the Local Government: Municipal
Structures Act, Act No. 117 of 1998, as amended. This Act allocates the functions of (bulk) water, (bulk) sanitation, municipal health and (bulk) electricity to the district municipalities, but also makes provision for the National Minister of Local Government to authorise a local municipality to exercise these powers and functions in its areas of

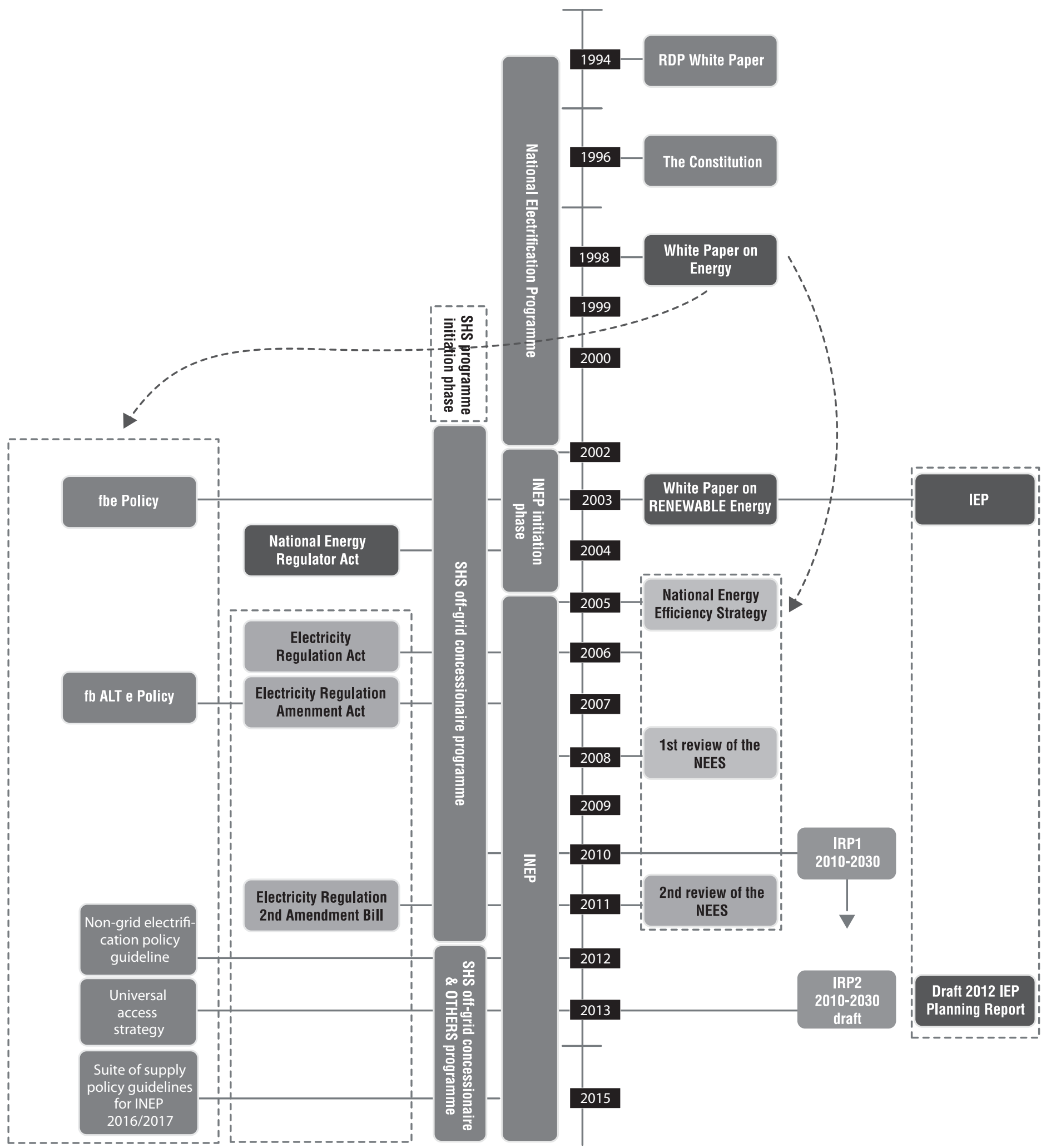

Figure 3: Timeline of key policies impacting rural electrification in South Africa (Scharfetter, 2016). 
jurisdiction instead of the district one (DWAF, 2007). For the implementation of rural electrification projects at local government level, it is important to take cognisance of how the powers and functions relating to electricity service provision are divided between district and local municipalities, and whether or not municipalities have the capacity to fulfil their designated powers and functions.

The Local Government: Municipal Systems Act, Act No. 32 of 2000, gives municipalities the authority to provide services, and gives them the option of either providing municipal services themselves or appointing appropriate service providers to undertake those services on their behalf, through a service delivery agreement between the municipality and the service provider. This Act thus introduces the concepts of services authority and services provider (South Africa, 2000). The legislative and executive authority function of a municipality, as defined by section 12 of the Municipal Systems Act, includes the development of policies and by-laws (e.g., tariffs, rates and taxes, and debt collection policies), deciding on the appropriate means of providing municipal services, preparing and managing budgets and arranging suitable financing for services (SALGA, 2014; South Africa, 2000). It is important to note that only a municipality can be allocated the powers and functions for the authority role. However, any capable legal entity can be contracted by the municipality to provide the services provision function (DWAF, 2007). Further, no person may act as a services provider without the approval of the services authority. In the cases of water, electricity and health, the default position was that the services authority would be the district municipality, unless a local municipality was authorised by the Minister of Local Government to perform the function. In the water sector a process was initiated in 2003 that clearly defined each municipality's role, whether district or local, as either water services authority or water services provider, or both. In the electricity sector, such a process was never initiated, as it was anticipated that the electricity sector was going to be restructured into regional electricity distributors. As a result, confusion exists in the electricity sector as to which municipalities have electricity services authority status (SALGA, 2014). Lack of clarity regarding the allocation of services authority responsibilities could potentially create uncertainty when deciding on an appropriate operating mechanism for a small-scale hydropower plant, specifically around contracting mandates. Cognisance must also be kept of the fact that the DoE makes use of Eskom and municipalities as implementing agents for the grid-connecting portion of the INEP, and transfers funds to these entities to implement the objectives of the INEP.

\section{National sector legislation}

The Electricity Regulation Act (ERA), Act No. 4 of 2006, as amended, describes the responsibilities and powers of the National Energy Regulator of South Africa (NERSA), specifically in regards to the processing and issuing of electricity generation, transmission and distribution licences, and electricity trading licences. The Act establishes a national framework for the electricity sector, from generation to distribution (City of Cape Town, 2015). The ERA specifies that NERSA must consider applications for licences, and may issue licences for the construction and operation of generation facilities and the construction and operation of a power distribution system (DoE, 2011a). Further, the ERA is very clear in its description of activities that require licencing: it states that no person may, without the appropriate licence issued by NERSA, construct or operate any generation facility and construct or operate any power distribution system (DoE, 2011a). The 2nd Amendment Bill includes an exception to this requirement:

[A] person who operates a distribution power system located solely on private property:

- Need not apply for or hold a trading licence, provided that such person does not sell electricity to its customers at a price higher than the price at which the electricity would be sold to those customers by the person from whom that operator purchases the electricity and

- Need not apply for or hold a distribution licence. (DoE, 2011a)

The Department of Rural Development and Land Reform commenced a process to audit South Africa's land ownership status. For small-scale hydropower projects for rural electrification in areas where land ownership is in flux, it will be important to know the status of land ownership for distribution licensing requirements. Even though the Bill has not been enacted yet, the intent of the DoE and NERSA in this regard is noted, and NERSA should be engaged with on a case-by-case basis to confirm whether or not a distribution licence will be required. It could be that an electricity distribution licence will be required for a mini-grid system, unless the system is to be implemented on privately owned land. Associated with the attainment of an electricity distribution licence is tariff approval. The Act further requires that an application for an electricity generation licence must include evidence of compliance with the Integrated Resource Plan (IRP) of the time, or provide reasons for any deviation (DME, 2006). The IRP is a national electricity plan and a subset of the Integrated Energy Plan. The IRP is also not a short- or medium-term operational plan but one that directs the expansion of the elec- 
tricity supply over the given period, including emphasising the objectives for the development of renewable energy technologies. The 2011-promulgated IRP emphasises security of electricity supply and is therefore focused on sources of electricity and the extent of electricity generated that is to be transmitted and distributed via grid infrastructure. Under section 7 of the 2011 IRP, which highlights the research agenda for the next IRP, it is stated that 'Off-grid activities should be considered especially as there is an impact on the potential future demand (through "suppressed demand" which has occurred as a result of lack of grid access for a number of potential consumers)' (DoE, 2011b). The 2013 non-promulgated and updated version of the IRP was silent on both the recommendation given in the 2011 version regarding the impact of off-grid electrification on supply demand, and the new household electrification strategy'. An updated IRP is being developed by the DoE for promulgation during 2017.

It is inferred that the ERA specifications regarding the conditions under which NERSA may issue generation licences, namely only for projects that are identified in the IRP, or are subject to a Section 34 determination as per the Act, were written for projects that will contribute to the country's generation mix, and which projects' electricity will be transmitted and distributed through an interconnected distribution system.

Conditions governing the issuing of generation licences are linked to the intended use of the electricity. Electricity generated from renewable energy sources, including small-scale hydropower schemes, can be used in different ways, as follows:

- islanded use;

- synchronised to the grid without feed in (commonly referred to as 'own use');

- connected to a municipal electricity distribution network; and

- connected to the Eskom electricity distribution network.

Combinations and variations of the above mentioned categories are also possible.

Rural electrification would be typically classified as 'islanded use'. Electricity generated for 'islanded use' is completely independent of municipal or Eskom distribution networks and can be applied for commercial or non-commercial purposes (Van Vuuren et al., 2014). Electricity generated for 'islanded use' and used for non-commercial purposes does not require a NERSA electricity generation licence. Electricity generated for commercial purposes does require a NERSA electricity generation licence (DME, 2006). No definition of 'commercial' use is given, but it is assumed that the application of a rural electrification project through mini-grids is a commercial activity and would therefore require a NERSA generation licence. This assumption is made given that there is a flow of grant funds and the potential exists for households to use more than $50 \mathrm{kWh}$ of electricity in a month, which would necessitate payment. Tables 1 and 2 summarise the current legislative and regulatory requirements to implement non-grid electrification schemes in South Africa.

It is recommended that NERSA be approached on a project-by-project basis, assuming that both an electricity generation and electricity distribution licence could be required. The right to exempt an applicant from the need to hold such licences rests with NERSA. Tables 1 and 2 indicate that applications to NERSA for an electricity generation licence require both an environmental authorisation and a water use authorisation as per the National Environmental Management Act and the National Water Act, respectively. Permission from the landowner to install an electricity generation scheme is also required.

The National Environmental Management Act, No. 107 of 1998, (NEMA), as amended, promotes the application of environmental assessment and management tools to ensure integrated environmental management of activities. The Act aims to improve the quality of environmental decision-making by setting out principles for environmental management that apply to all government departments and to all organisations that may affect the environment (DEAT, 1998). Section 23 of the NEMA provides the general objectives of integrated environmental management, and section 24 outlines the procedures to be implemented in order to achieve these objectives (DEAT, 2004). An implementation tool of integrated environmental management is the environmental impact assessment, or EIA. An EIA is a procedure which ensures that the environmental consequences of projects are identified and assessed before an environmental authorisation (previously referred to as 'record of decision') by a competent authority is given (DEA, 2015). A competent authority is either the Minister of Environmental Affairs, through the Department of Environmental Affairs, or a member of the executive council of a province who has been assigned responsibility for the environmental portfolio (DEA, 2014). The EIA serves to identify, predict, evaluate and mitigate any environmental impacts of a proposed development (DEAT, 2004). Regulations in terms of Chapter 5 of the NEMA were published in April 2006, and revised in June 2010 and again in December 2014. These regulations, published as general notices (GN) GN983, GN984 and GN985 in the Government Gazette, provide procedures to guide the submission and evaluation of applications for environmental authorisations, including identifying the relevant competent authority. At the initiation phase of any project or development, the extent of the potential environmental impact is 
Table 1: Electricity generated for islanded use (commercial).

\begin{tabular}{|c|c|c|c|c|c|}
\hline $\begin{array}{l}\text { NERSA } \\
\text { generation } \\
\text { licence }\end{array}$ & $\begin{array}{c}\text { Local electricity } \\
\text { utility } \\
\text { involvement }\end{array}$ & $\begin{array}{l}\text { Proof of land } \\
\text { ownership / permis- } \\
\text { sion to use land }\end{array}$ & $\begin{array}{c}\text { Environmental } \\
\text { authorisation }\end{array}$ & $\begin{array}{c}\text { Water use } \\
\text { authorisation }\end{array}$ & $\begin{array}{c}\text { Water allocation } \\
\text { confirmation }\end{array}$ \\
\hline $\begin{array}{l}\text { Yes (a distri- } \\
\text { bution licence } \\
\text { might also be } \\
\text { required) }\end{array}$ & $\begin{array}{l}\text { Yes } \\
\text { If a municipality } \\
\text { would like to act } \\
\text { as implementer of } \\
\text { non-grid electrification } \\
\text { through the INEP in } \\
\text { areas outside of SHS } \\
\text { concessionaire areas, } \\
\text { then applications to } \\
\text { the DoE are to be done } \\
\text { by the local } \\
\text { municipality }\end{array}$ & $\begin{array}{l}\text { Needed for } \\
\text { NERSA } \\
\text { licensing } \\
\text { requirements } \\
\text { ne }\end{array}$ & $\begin{array}{l}\text { Needs to be } \\
\text { addressed for } \\
\text { NERSA } \\
\text { licensing } \\
\text { requirements } \\
\text { Yes, if required } \\
\text { by NEMA } \\
\text { Notice by environ- } \\
\text { mental practitioner } \\
\text { if none is required }\end{array}$ & $\begin{array}{l}\text { Needs to be } \\
\text { addressed for } \\
\text { NERSA } \\
\text { licensing } \\
\text { requirements }\end{array}$ & $\begin{array}{l}\text { Needs to be addressed } \\
\text { for NERSA licencing } \\
\text { requirements } \\
\text { If conduit hydropower } \\
\text { (see supplementary inform-. } \\
\text { ation in Section 10), the } \\
\text { Water Services Provider } \\
\text { must confirm that water is } \\
\text { available and hydropower } \\
\text { generation will not affect } \\
\text { security of supply. }\end{array}$ \\
\hline & & & & & $\begin{array}{l}\text { If conventional hydropower, } \\
\text { this will be addressed } \\
\text { through the water use } \\
\text { authorisationprocess }\end{array}$ \\
\hline
\end{tabular}

Table 2: Electricity generated for islanded use (non-commercial).

\begin{tabular}{|c|c|c|c|c|c|}
\hline $\begin{array}{l}\text { NERSA } \\
\text { generation } \\
\text { licence }\end{array}$ & $\begin{array}{c}\text { Local electricity } \\
\text { utility } \\
\text { involvement }\end{array}$ & $\begin{array}{l}\text { Proof of land } \\
\text { ownership / permis- } \\
\text { sion to use land }\end{array}$ & $\begin{array}{c}\text { Environmental } \\
\text { authorisation }\end{array}$ & $\begin{array}{c}\text { Water use } \\
\text { authorisation }\end{array}$ & $\begin{array}{c}\text { Water allocation } \\
\text { confirmation }\end{array}$ \\
\hline No & $\begin{array}{c}\text { Good practice to } \\
\text { inform }\end{array}$ & Yes & $\begin{array}{c}\text { Yes, if required } \\
\text { by NEMA }\end{array}$ & $\begin{array}{l}\text { Yes, if required by } \\
\text { National Water Act } \\
\text { (if water resource is } \\
\text { directly impacted) }\end{array}$ & $\begin{array}{l}\text { If conduit hydropower, } \\
\text { water services provider } \\
\text { must confirm that water } \\
\text { s available and hydro- } \\
\text { power generation will not } \\
\text { affect security of water } \\
\text { supply and services }\end{array}$ \\
\hline & & & & & $\begin{array}{c}\text { If conventional hydropower, } \\
\text { this will be addressed } \\
\text { through the water use } \\
\text { authorisation process }\end{array}$ \\
\hline
\end{tabular}

anticipated through an initial screening process which consists of checking the proposed development activities against current legislation. The GN983 lists the activities, which, when triggered by a development, would initiate a basic assessment. A basic assessment is applied when the activities of a development are considered unlikely to have significant environmental impacts. A process of full public participation or stakeholder engagement is, however, still required. The GN984 lists activities, which, when triggered, would initiate a full EIA. The activities presented in this list would result in significant environmental impacts. The GN985 contains listed geographic activities, i.e. activities that stretch across borders or provincial boundaries. Figure 4 summarises the basic steps in each process.

Based on the electricity generation and distribution activity listings of GN983 and GN984, it is very likely that neither an EIA nor a basic assessment environmental authorisation will be required for the initiation and construction of the electricity genera- tion and distribution components of small-scale hydropower schemes. This should be confirmed on a case-by-case basis. Based on the water activity listings of GN983 and GN984, and depending on the actual scope of work of a particular small-scale hydropower rural electrification project, a basic assessment could possibly be required.

The National Water Act (NWA) of 1998, as amended, fundamentally changed the way water resources in South Africa are to be managed and used. The NWA is founded on the constitutional principle that water belongs to all the people of South Africa. It aims to protect, conserve, manage and control water resources as a whole (De la Harpe \& Ramsden, 1998) The only right to water encapsulated in the Act is for basic human needs and the environment, and the Act requires that water is 'reserved' for these needs before water is allocated for other uses. Water use is controlled through regulating the way it can be used. The NWA regulates water use through the registration of 


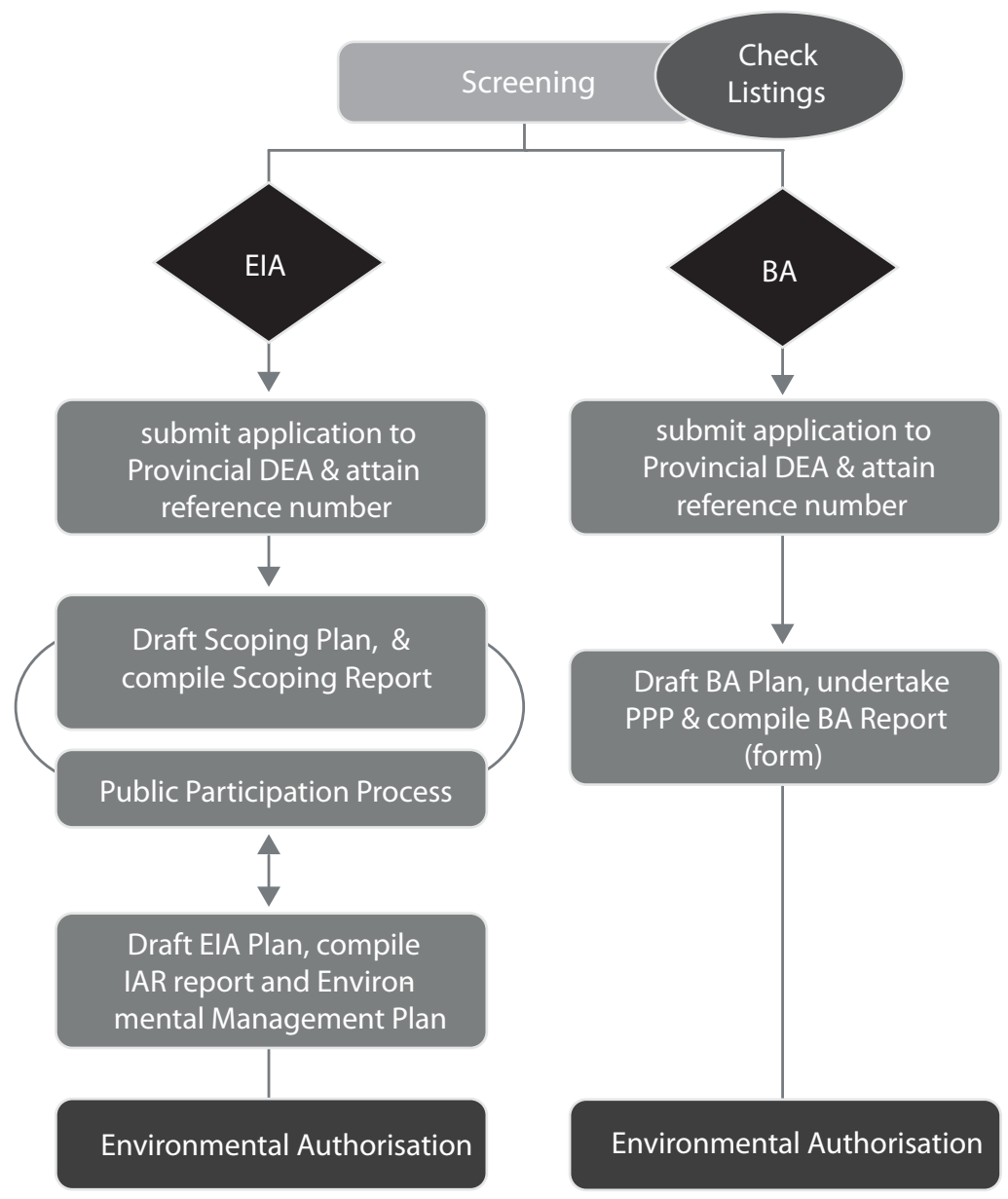

Figure 4: Typical processes associated with a basic assessment and an environmental impact assessment (Scharfetter, 2016).

existing lawful water use, and through different types of authorisations (De la Harpe \& Ramsden, 1998). Applications for water use registration or authorisation are to be submitted to the applicable catchment management agency (CMA) or protoCMA, if a CMA is not yet constituted. Three different categories of water use authorisation exist, as shown in Figure 5, but only two are of relevance for the development of small-scale hydropower projects. The first category does not require a licence or registration for water use, as defined in Schedule 1 of the NWA. Schedule 1 water uses are mainly domestic in nature, with minimal risk and impact on the water resource.

A set of 11 consumptive and non-consumptive water uses is defined, any one of which would require a water use authorisation:

21(a) taking water from a water resource;

21(b) storing water;

21(c) impeding or diverting the flow of water in a watercourse;

21(d) engaging in a stream flow reduction activity contemplated in section 36 ;

$21(e)$ engaging in a controlled activity identified as such...; 21(f) discharging waste or water containing waste into a water resource through a pipe, canal, sewer, sea outfall or other conduit;

$21(\mathrm{~g})$ disposing of waste in a manner which may detrimentally impact on a water resource;

21(h) disposing in any manner of water which contains waste from, or which has been heated in, any industrial or power generation process;

21(i) altering the bed, banks course or characteristics of a watercourse;

21(j) removing, discharging or disposing of water found underground if it is necessary for the efficient continuation of an activity or for the safety of people; and

21(k) using water for recreational purposes. (DWAF, 1998)

Of these clauses, 21(c) and 21(i) are of particular relevance to small-scale hydropower projects.

Water use authorisation: Registration in terms of a general authorisation

General authorisations (GAs) allow the Department 


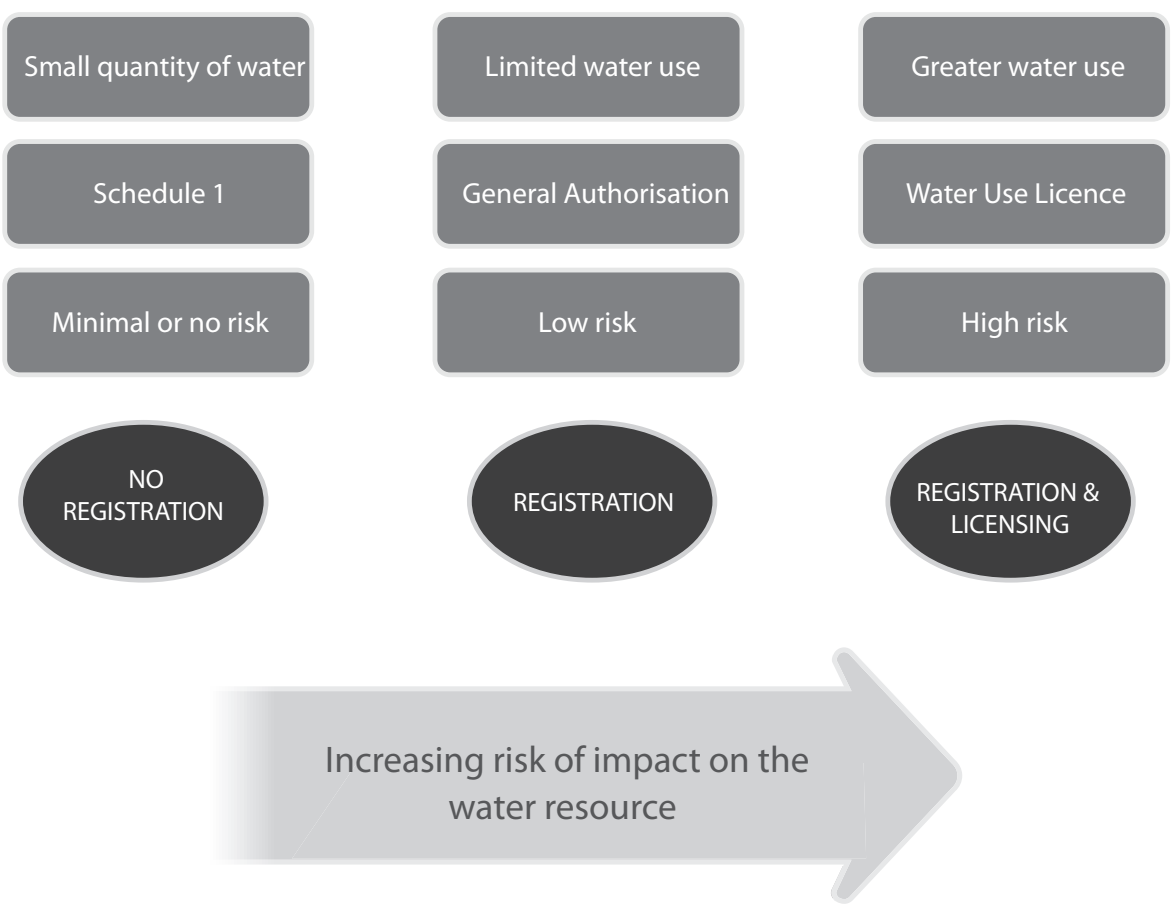

Figure 5: Three types of water use authorisations (De la Harpe \& Ramsden, 1998).

of Water and Sanitation to authorise large numbers of people to take up water without the need for a licence. A GA can be limited to a specific group of people, and/or specific water resources, and has several advantages, including:

- Smaller scale emerging users would not need to be ready to apply for a licence;

- General Authorisations can be adapted for specific regional and social needs;

- General Authorisations can promote the uptake of smaller amounts of water by many people - and hence can have a greater impact on poverty;

- They can reduce the administrative burden;

- They can allow for the gradual uptake of water by the poor, paralleled with the gradual reduction of use by existing lawful water users.' (Department of Water and Sanitation, n.d.)

In terms of section 39 of the NWA, GAs are published periodically (normally every five years) in the Government Gazette. If the intended water use activity is covered under a GA then a registration process is to be followed. Importantly, a GA is only applicable to specific rivers or catchments and not to the whole country. On 26 August 2016, a revised and updated GA was gazetted in General Notice 509 of 2016: 'General Authorisation in terms of Section 39 of the National Water Act 1998 (Act no 36 of 1998) for water uses as defined in section 21(c) or section 21 (i)'. This GA now includes the following activity, under Appendix D2:

\begin{tabular}{|c|c|}
\hline $\begin{array}{l}\text { SOC's, Institution } \\
\text { or Individual }\end{array}$ & \\
\hline $\begin{array}{l}\text { Municipalities and } \\
\text { other institutions }\end{array}$ & $\begin{array}{l}\text { Mini-scale hydropower devel- } \\
\text { opment with a maximum } \\
\text { capacity of } 10 \mathrm{~kW} \text { to } 300 \mathrm{~kW} \\
\text { (Read together with General } \\
\text { notice } 665 \text { of } 6 \text { Sept } 2013 \\
\text { General Authorisation section } \\
21(e) \text { or as amended) }\end{array}$ \\
\hline
\end{tabular}

These hydropower plants will provide basic, nongrid electricity to rural communities and agricultural land and must in no way affect the flow regime, flow volume and/or water quality including temperature.

The SHP projects initiated and implemented for islanded, non-grid electrification purposes would only need to follow a registration process to obtain the required water use authorisation, and not a full water use licence application process, saving time and costs. The registration process for an activity listed in a GA entails compiling a document pack that includes the following information, as shown in Figure 6:

- part 1: Form detailing the applicant type;

- $\quad$ part 2: Forms detailing the intended water uses; a form per water use is to be completed; and

- substantiating documentation as per the GA and the published risk matrix.

The regional office to which the submission was made will issue a registration number to the applicant after the application has been reviewed and 
Water use authorisation given per portion of property

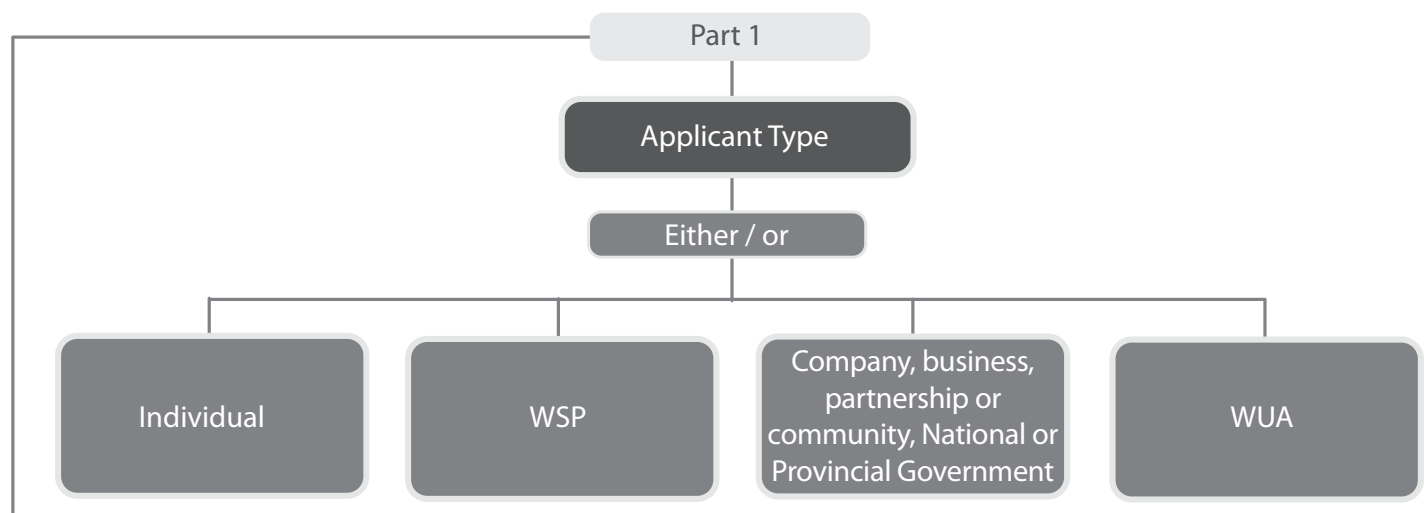

Property relationship details

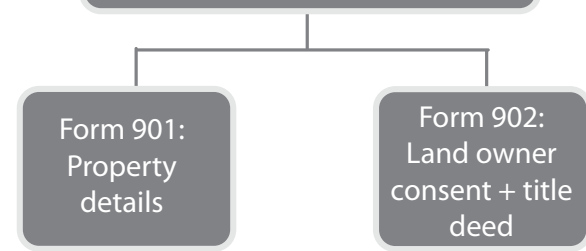

Part 2
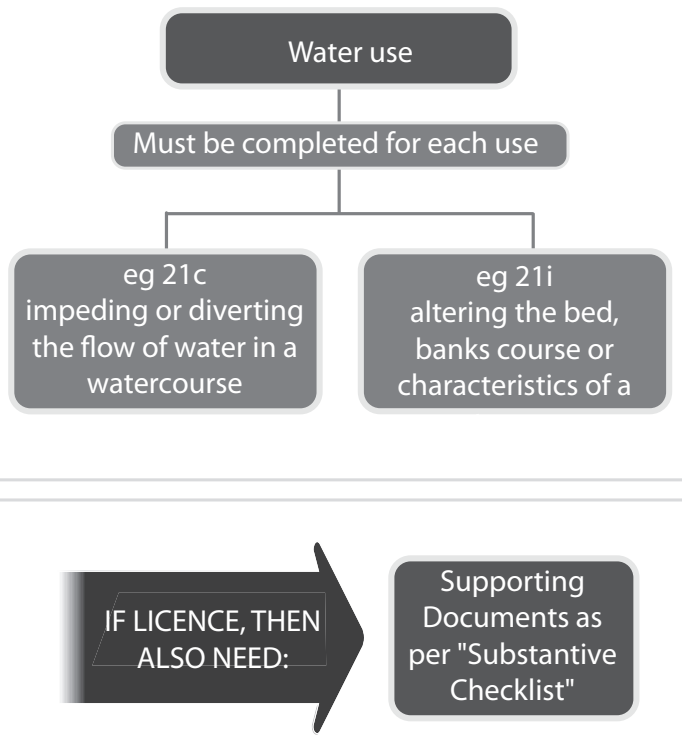

Supporting

Documents as

per "Substantive

Checklist"

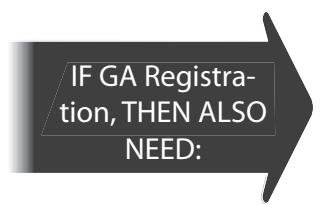

Supporting

Documents as

per "Risk Matrix"

Figure 6: Submission documentation required for both a water use licence and the GA registration (Scharfetter, 2016).

25 Journal of Energy in Southern Africa • Vol 28 No 2 • May 2017 
approved, with the understanding that the applicant will honour the conditions of the authorisation.

\section{Water use authorisation: Water use licensing}

If the intended use is not covered in a GA, then a licencing process is required (see Figure 6).

An application for an electricity generation licence, an electricity distribution licence, a water use authorisation or an environmental authorisation must show that the permission of the land-owner to use the land has been attained, if the land is not owned by the developer. In South Africa, given the dispossession of the land and subsequent attempts to address this dispossession, it is important to know who owns the property and what land use rights have been vested to that property and to whom. Land can be owned privately or by the state.

Privately owned (or non-state owned) land includes land owned by:

- a community property association, or CPA. A CPA is a legal body that can be established by communities in order to submit land claims through the Restitution or Redistribution land reform programmes (DLA, 1997). The establishment of CPAs is legally governed by the Communal Property Associations Act, Act No. 28 of 1996. The Act is aimed at enabling communities 'to form juristic persons, to be known as communal property associations, to acquire, hold and manage property on a basis agreed upon by members of a community in terms of a written constitution, and to provide for matters connected therewith' (DLA, 1996);

- municipalities (municipal commonage);

- traditional authorities and registered by the deeds office (DRD \& LR, 2013); and

- individuals.

State-owned land (i.e. owned by national or provincial government) includes:

- land owned by the state but administered by trusts or other entities, for example the Ingonyama Trust in KZN (DRD \& LR, 2013). The land is owned by the state, but is administered on behalf of the community by the trust. The land is therefore held in trust by the state and is not owned by the community or communities;

- state assets and developed state land. The Department of Public Works is usually the custodian of state-owned land (SANRAL, 2008), and in particular all state assets and developed state land (Umhlaba Consulting Group, 2013);

- land under various tribal authorities. The Minister of Rural Development and Land Reform is the custodian of state-owned land on behalf of (inter alia) various tribal authorities (SANRAL, 2008).
For development purposes, land is either acquired, and the land-use rights changed if necessary, or permission to use the land is obtained from the land-owner, and a servitude registered in the name of the land user for the portion of land subject to development. Importantly, any community or communities living on the land must pass a resolution to approve the servitude and land use before a landowner would be able to grant the servitude.

\section{Way forward}

The aim of the research was to initiate, plan, design and implement small-scale hydropower projects for non-grid rural electrification in two district municipalities in South Africa, namely the O.R. Tambo District Municipality in the Eastern Cape Province and the Umzinyathi District Municipality in the KwaZulu-Natal Province. A suitable project site was identified on the Thina River within the Mhlontlo Local Municipality, and a $50 \mathrm{~kW}$ run-of-river type scheme has been designed and constructed which is able to provide at least a basic energy service to the approximate 50 households of the KwaMadiba community. Once the scheme is commissioned, actual demand and supply dynamics, consumption patterns and improvements in quality of life that result from such a stand-alone, mini-grid system in the context of rural electrification, will be analysed and compared to the desktop studies undertaken on those aspects.

\section{Conclusions}

In South Africa, the electricity sector is governed by robust legislation such as the National Electricity Regulation Act; by policies such as the White Paper on Renewable Energy and the free basic electricity support tariff policy; and by strategies such as the 'new household electrification strategy'. In addition to complying with the requirements of the Electricity Regulation Act, SHP projects towards non-grid rural electrification will need to comply with the requirements of the NEMA and the NWA. With regard to the NWA, this research project led to the inclusion of run-of-river type small-scale hydropower projects for rural electrification in the 2016 updated GA. This implies that these types of SHP projects would only need to follow a registration process to obtain the required water use authorisation, and not a full water use licence application process, saving time and costs, benefitting the owner municipality and the communities served. Small-scale hydropower projects for non-grid rural electrification in South Africa would typically be implemented by local government, as it is their constitutional mandate to ensure service delivery. Even though the Constitution deems that electricity generation is exclusively a national government function, rural, non-grid electrification, at such small scales as would be implemented through the new household 
electrification strategy' and as islanded systems, is not considered contrary to the principles of the Constitution. The implementation of SHP projects requires intergovernmental coordination both horizontally across sectors and departments and vertically across the three spheres of government due to its multi-sectoral nature. South Africa's robust legislative architecture in the water, environmental and energy sectors provides opportunities for the implementation of small-scale hydropower projects applied for non-grid rural electrification. Taking cognisance of this dynamic regulatory environment, and the individual nature of each project, recent legislation and regulations should be consulted on a case-by-case basis as part of the feasibility analysis of a project.

\section{Acknowledgements}

This research was funded by the Department of Science and Technology and the Water Research Commission, whose support is acknowledged with gratitude.

\section{References}

Alliance for Rural Electrification. 2014. The potential of small hydro for rural electrification, Focus: Latin America. Available online at: https://www.ruralelec. org/publications/potential-small-hydro-rural-electrification-focus-latin-america (accessed 27 February 2015).

Azimoh, C. and Klintenberg, P. K. B. 2015. Illuminated but not electrified: An assessment of the impact of Solar Home System on rural households in South Africa. Applied Energy, 155: 354-364.

Azimoh, C., Klintenberg, P., Wallin, F., Karlsson, B., and Mbohwa, C. 2015. Electricity for development: Minigrid solution for rural electrification in South Africa. Energy Conversion and Management, 110: 268277.

Bekker, B., Eberhard, A., Gaunt, T. and Marquard, A. 2008. South Africa's rapid electrification programme: Policy, institutional planning, financing and technical innovations. Energy Policy, 36: 3125-3137.

British Hydropower Association. 2012. A guide to UK mini-hydro developments, Version 3.0. Available online at: http://www.british-hydro.org/ (accessed 27 February 2015).

City of Cape Town. 2015. Cape Town: State of energy 2015. Cape Town: City of Cape Town.

De la Harpe, J. and Ramsden, P. 1998. Guide to the National Water Act. Pretoria: Department of Water Affairs and Forestry.

De Visser, J. 2012. Cities and climate change Ex abundanti cautela - 'from an excess of caution?'. In: A. Cartwright, S. Parnell, G. Oelofse and S. Ward, eds. Climate change at the city scale: Impacts, mitigation and adaptation in Cape Town. New York: Routledge, 122-146.

Department of Energy (DoE). 2011a. Electricity Regulation Second Amendment Bill. Available online at: http://www.energy.gov.za/ (accessed 1 March 2014).
Department of Energy (DoE). 2011b. Integrated Resource Plan for Electricity 2010-2030, Revision 2. Available online at: www.energy.gov.za/IRP/ (accessed 28 September 2015).

Department of Energy (DoE). 2013. Presentation on the Integrated Electrification Programme to the NCOP Economic and Business Development Committee, 10 September 2013. Available online at: https://pmg.org.za/committee-meeting/16322/ (accessed 11 August 2014).

Department of Energy (DoE). 2014. Annual report 2013/14. Available online at: http://www.energy.gov.za/ (accessed 1 April 2015).

Department of Energy (DoE). 2015. State of renewable energy in South Africa. Available online at: http://www.gov.za/ (accessed 5 November 2015).

Department of Environmental Affairs. 2015. EIA guideline for renewable energy projects. Available online at: https://www.environment.gov.za/sites/ default/files/legislations/EIA_guidelineforrenewableenergyprojects.pdf (accessed 30 June 2015).

Department of Environmental Affairs. 2014. National Environmental Management Act, Act No.107 of 1998: Environmental Impact Assessment Regulations. Available online at: https://www.environment.gov.za/ (accessed 7 July 2015).

Department of Environmental Affairs and Tourism (DEAT). 1998. National Environmental Management Act. Available online at: https://www.environment. gov.za/ (accessed September 2012).

Department of Environmental Affairs and Tourism (DEAT). 2004. Overview of integrated environmental management. Available online at: https://www.environment.gov.za/ (accessed September 2012).

Department of Land Affairs. 1996. The Communal Property Association Act, Act No.28 of 1996. Available online at: http://www.ruraldevelopment. gov.za/legislation-and-policies/file/116-communalproperty-associations-act-28-of-1996 (accessed 25 November 2015).

Department of Land Affairs. 1997. White Paper on South African Land Policy. Available online at: http://www.ruraldevelopment.gov.za/phocadownload/White-Papers/whitepaperlandreform.pdf (accessed 25 November 2015).

Department of Minerals and Energy (DME). 1998. White Paper on the Energy Policy of South Africa. Available online at: http://www.gov.za/ (accessed 7 April 2013).

Department of Minerals and Energy (DME). 2006. Electricity Regulation Act, Act No.4 of 2006. Available online at: http://www.gov.za/ (accessed 7 April 2013).

Department of Rural Development and Land Reform. 2013. Rural development and land reform: Survey and registration of state-owned-land, the creation of a comprehensive land register and the scarce skills training programme: Briefing by the Department of Rural Development and Land Reform. Available online at: https://pmg.org.za/committee-meeting/ 15459/ (accessed 25 November 2015).

Department of Water Affairs and Forestry (DWAF). 
1998. National Water Act. Available online at: www.dwaf.gov.za/Documents/Legislature/nw_act/NW A.htm (accessed 27 September 2015).

Department of Water Affairs and Forestry (DWAF). 2007. Water Services Authority Legislative Handbook. Pretoria: Department of Water Affairs and Forestry.

Department of Water and Sanitation, n.d. What are General Authorisations? Available online at: http://www.dwa.gov.za/WAR/generalauthorisations.as px (accessed 15 July 2015).

Downing, T. 2011. Adaptation to X: Mapping decision spaces. Oxford: Global Adaptation Partnership.

Eberhard, A. 2013. An overview of the restructuring of the South African Electricity Distribution Industry: South African Local Government Association stakeholder workshop. Available online at: http:/www. gsb.uct.ac.za/files/salgaworkshop.pdf (accessed 15 April 2015).

Fichtner Management Consulting AG. 2015. Hydroelectric power: A guide for developers and investors. New York: IFC World Bank Group. Available online at: http://www.ifc.org/wps/wcm/connect/topics_ext_content/ifc_external_corporate_site/if c+sustainability/learning + and+adapting/knowledge + products/publications/hydroelectric_power_a guide_for_developers_and_investors (accessed 5 March 2015).

Jamal, N. 2015. Options for the supply of electricity to rural homes in South Africa. Journal of Energy in Southern Africa 26(3): 58-65.

Jonker Klunne, W. 2012. Current Status and future developments of small and micro hydro in Southern Africa, paper presented to hidroenergia, Wroclaw, May 2012. Available online at: http://energy4africa. net/klunne/publications/ (accessed 9 December 2015).

Kusakana, K. 2014. A survey of innovative technologies increasing the viability of micro-hydropower as a cost effective rural electrification option in South Africa. Renewable and Sustainable Energy Reviews 30: 370-379.

Le Cordeur, M. 2015. FIN24: New electricity bill underway - energy ministry. Available online at: http://fin24.com/Economy/New-Ismo-bill-beingplanned-energy-ministry-2015 (accessed 11 June 2015).

Loots, I., van Dijk, M., Barta, B., van Vuuren, S.J. and Bhagwan, J.N. 2015. A review of low head technologies and applications in a South African context Renewable and Sustainable Energy Reviews 50: 1254-1268

National Treasury. 2015. Estimates of national expenditure. Available online at: www.treasury.gov.za/documents/national\%20budget/2015/ene/FullENE.pdf (accessed 15 April 2015).

Nhamo, G. and Mukonza, C. 2016. Policy, institutional and programme readiness for solar energy uptake in South Africa. Africa Insight 45(4): 69-90.

Paish, O. 2002. Small hydro power: Technology and current status. Renewable and Sustainable Energy Reviews 6(6): 537-556.

Scharfetter, B.G. 2016. A roadmap for navigating the institutional complexities of implementing small-scale hydropower projects for rural electrification in South Africa. Masters dissertation, University of Pretoria. Available online at: http://repository.up.ac.za/handle/2263/57502 (accessed June 2016).

South Africa. 1994. White Paper on Reconstruction and Development. Available online at: www.gov.za/ sites/www.gov.za/files/governmentgazetteid16085.pdf (accessed 3 November 2015).

South Africa. 1996. Constitution of the Republic of South Africa, Act No.108 of 1996. Available online at: http://www.gov.za/DOCUMENTS/CONSTITUTION/constitution-republic-south-africa-1996-1 (accessed 7 April 2013).

South Africa. 2000. Local Government: Municipal Systems Act, Act No.32 of 2000. Available online at: www.gov.za/documents/local-government-municipalsystems-act (accessed 7 April 2013)

South African Local Government Association (SALGA). 2014. The role of municipalities as a service authorities for electricity provision. Available online at: https://ameu.co.za/ (accessed 15 June 2015).

South African National Roads Agency Limited (SANRAL). 2008. SANRAL Land acquisition guideline manual for consulting engineers, Pretoria. Available online at: https://nra.co.za/ (accessed 26 November 2015).

Taele, B., Mokhutsoane, L. and Hapazari, I. 2012. An overview of small hydropower development in Lesotho: Challenges and prospects. Renewable Energy 44: 448-452.

Umhlaba Consulting Group. 2013. Land and settlement development research study, Report on: land acquisition and transfer, s.l.: Afesis-corplan.

Van Vuuren, S. Loots, I., van Dijk, M., Barta, B., and Scharfetter, B.G. 2014. Conduit hydropower development guide, WRC report nr: TT 597/14, Pretoria: Water Research Commission.

Winkler, H., Davidson, O., Kenny, A., Prasad, G., Nkomo, J., Sparks, D., Howells, M. and Alfstad, T. 2006. Energy policies for sustainable development in South Africa: Options for the future. Cape Town: Energy Research Centre. 